\title{
EKONOMSKI, TRGOVINSKI I JEZIKOSLOVNI KONTEKST TISKANJA PRVE FRANCUSKO-HRVATSKE GRAMATIKE I FRANCUSKO-HRVATSKOGA RJEČNIKA (1869.)
}

\author{
ECONOMIC, TRADE AND LINGUISTIC CONTEXT \\ OF THE FIRST FRENCH-CROATIAN GRAMMAR \\ AND FRENCH-CROATIAN DICTIONARY (1869)
}

\begin{abstract}
SAŽETAK: U ovome radu nastoji se napraviti pregled ekonomskih, trgovinskih i jezikoslovnih okolnosti te poticaja za tiskanje (u Zagrebu 1869.) prve francusko-hrvatske gramatike i francusko-hrvatskoga rječnika Paula Pierrea pod naslovom Abrégé de grammaire français-croate et de dictionnaire français-croate (Pregled francusko-hrvatske gramatike i francusko-hrvatskoga rječnika). To je djelo bilo namijenjeno francuskim trgovcima u Hrvatskoj koji nisu imali prikladan priručnik za hrvatski jezik.
\end{abstract}

KLJUČNE RIJEČI: prva francusko-hrvatska gramatika, francusko-hrvatski rječnik, ekonomski, trgovinski i jezikoslovni kontekst.

SUMMARY: In this paper, the aim is to present an overview of economic, trade and linguistic circumstances and the encouragement of printing (in Zagreb in 1869) the first French-Croatian grammar and the French-Croatian dictionary by Paul Pierre entitled Abrégé de grammaire français-croate et de dictionnaire français-croate (An overview of the French-Croatian grammar and the French-Croatian dictionary). Pierre's work was intended for French merchants in Croatia who didn't have a suitable manual in Croatian.

KEY WORDS: first French-Croatian grammar, French-Croatian dictionary, economic, trade and linguistic context. 


\section{UVOD}

O prvoj francusko-hrvatskoj gramatici te priključenom francusko-hrvatskom rječniku Paula Pierrea Abrégé de grammaire français-croate et de dictionnaire français-croate usustavljeno je pisao istaknuti hrvatski jezikoslovac, romanist Valentin Putanec u tekstu "La Grammaire croate et le petit dictionnaire français-croate de Paul Pierre", koji je objavljen u godišnjaku Annales de l'Institut français de Zagreb. ${ }^{1}$ Taj nam je tekst poslužio kao jedan od najvažnijih poticaja i izvora za ovaj rad.

Svrsishodno je u uvodu navesti Putančev zaključak da nije riječ o "remek-djelu" sa znanstvenim obilježjima, nego "o maloj kompilaciji gramatike i leksikografije toga doba".2 To je djelo "nastalo prema zamolbi nekoliko Francuza koji su živjeli u Hrvatskoj kako bi se lakše snašli u uporabi hrvatskoga poslovnog jezika"3, koji je već u 1860-im godinama hrvatski jezikoslovac i polihistor Bogoslav Šulek genijalno obogaćivao novim znanstvenim nazivljem (prirodoslovnim, botaničkim, šumarskim). ${ }^{4}$

Pregledom i istraživanjem ekonomskoga, trgovinskoga i jezikoslovnoga konteksta potkrjepljivana je tvrdnja o namjeri tiskanja te gramatike i rječnika radi svakodnevnih komunikacijskih potreba francuskih trgovaca u Zagrebu i cijeloj Hrvatskoj (Trojednoj Kraljevini Hrvatskoj, Slavoniji i Dalmaciji) tijekom 1860 -ih i 1870 -ih godina. ${ }^{5}$ Usput su ponovljene i djelomice obrazložene stare tvrdnje o međuovisnostima hrvatskoga gospodarstva i hrvatske kulture, kao što je to oduvijek diljem svijeta.

\section{DRVO - GLAVNI HRVATSKI IZVOZ U 1860-ima}

Rudolf Bićanić je tvrdio kako je još 1824. riječki veletrgovac Andrija Ljudevit Adamić (Ludovik Andrea Adamich) doveo francuske trgovce drvom u Hrvatsku zainteresiravši ih osobito za slavonsku hrastovinu. ${ }^{6}$ Drvo, drvna građa i različiti drvni proizvodi činili su izrazito najveći dio hrvatskoga izvoza tijekom 1850-ih i 1860-ih godina u Francusku. ${ }^{7} \mathrm{U}$ drugoj su polovini 19. stoljeća slavonske šume hrasta lužnjaka, osim francuskih vinara, privlačile osobito još europske pivare, graditelje kuća, mostova i željezničkih pruga. ${ }^{8}$ Budući da je intenzivirana njihova gradnja, brzo je rastao francuski i njemački interes za željeznič-

\footnotetext{
Valentin Putanec, «La Grammaire croate et le petit dictionnaire français-croate de Paul Pierre», Annales de l'Institut français de Zagreb, IX, 1945., str. 243-266.

Isto, str. 264.

Isto.

Bogoslav Šulek (1816. - 1895.), rođeni Slovak, hrvatski narodni preporoditelj, znameniti hrvatski pisac, polihistor, znanstvenik, jezikoslovac, genijalni leksikograf koji je presudno utjecao na razvojni put hrvatskoga književnog jezika. Gotovo šest desetljeća neizmjerno je doprinosio svojoj novoj domovini Hrvatskoj.

V. Putanec, n. dj., str. 264.

Rudolf Bićanić, Doba manufakture u Hrvatskoj i Slavoniji (1750. - 1860.), Zagreb, 1951., str. 106.

Zlata Živaković-Kerže, "Šuma/drvo - iskorištena ili neiskorištena mogućnost. Prilog povijesnom razmatranju drvne eksploatacije na prijelazu 19. u 20. stoljeće», u: Dinko Župan i Robert Skenderović (ur.), Slavonske šume kroz povijest, Hrvatski institut za povijest, Podružnica za povijest Slavonije, Srijema i Baranje, Slavonski Brod, 2017., str. 261-280. Isto, str. 266-267., 274. i 277.
} 
ke pragove, stoga su se neki hrvatski trgovci još u prvom dijelu 1850-ih zbog dobre zarade usmjerili na njihovu proizvodnju. ${ }^{9}$

O povijesti slavonskih šuma Mira Kolar-Dimitrijević objavila je sintetski tekst "Kratak osvrt na povijest šuma Hrvatske i Slavonije od 1850. godine do Prvoga svjetskog rata" koji je objavljen u Časopisu za gospodarsku povijest i povijest okoliša Ekonomska i ekohistorija.$^{10}$ Sugestivno je obrazložila ekonomsku važnost izvoza drva za onodobnu Hrvatsku (i Slavoniju), ali i jasno sugerirala da su od tih velikih hrvatskih šumskih bogatstava, ipak, najviše koristi tradicionalno izvlačili Austrijanci i Mađari, osobito Habsburški dvor. ${ }^{11}$ Posebnu je pozornost posvetila izvozu dužica (duga) za bačve u Francusku, ali i drvenih pragova za željezničke pruge. ${ }^{12}$ Apostrofirala je ozakonjenje eksploatacije drva donošenjem austrijskoga Zakona o šumama (1852.) $)^{13}$ koji se počeo primjenjivati u civilnoj Hrvatskoj 1857., a u Vojnoj krajini tek $1860 .{ }^{14}$ Poticajno je protumačila kako su šume "bile ključni faktor prestrukturiranja u moderno društvo" ${ }^{15}$ u okolnostima dok je izrada dužica za građu bačava povećana pet puta od $1830 .{ }^{16}$ te pojasnila zašto je 1866. sređen "novi inventar šuma po županijama u cijeloj Hrvatskoj i Slavoniji" ${ }^{17}$ Jasno je odredila razloge zbog kojih se razvila žestoka borba za šume među stranim i domaćim investitorima u drvnu industriju koja je donosila velike prihode. ${ }^{18}$

Zlata Živaković-Kerže apostrofirala je u znanstvenom radu "Šuma/drvo - iskorištena ili neiskorištena mogućnost (Prilog povijesnom razmatranju drvne eksploatacije na prijelazu 19. u 20. stoljeće)" povećanje izvoza drva nakon Velike gospodarske izložbe u Beču 1857. na kojoj su "izložene tvorevine od drva". ${ }^{19}$ Izdvojila je veliki interes francuskih i njemačkih trgovaca za drvo i drvnu građu što je "krajem 60-ih godina 19. stoljeća" u izvozu dostiglo do $32.000 .000,00$ hrastovih dužica za vinske i pivske bačve, a donosilo je "25.000.000 forinti": samo "iz Francuske 20.000.000". ${ }^{20}$ Komentirajući tvrdnje Bogoslava Šuleka iz njegove knjige Korist i gojenje šumah, osobito u Trojednoj Kraljevini (u koju je uveo novo znanstveno nazivlje: prirodoslovno, botaničko, šumarsko), ${ }_{,}^{21}$ napisanu "na poziv visokoga Kraljevskoga namjestničkoga vieća za kraljevine Dalmaciju, Hrvatsku i Slavoniju”, 22 Živaković-Kerže ustvrdila je kako su brzo rasle cijene dužica od hrastovine te istodobno povećavana proizvodnja željezničkih pragova. ${ }^{23}$

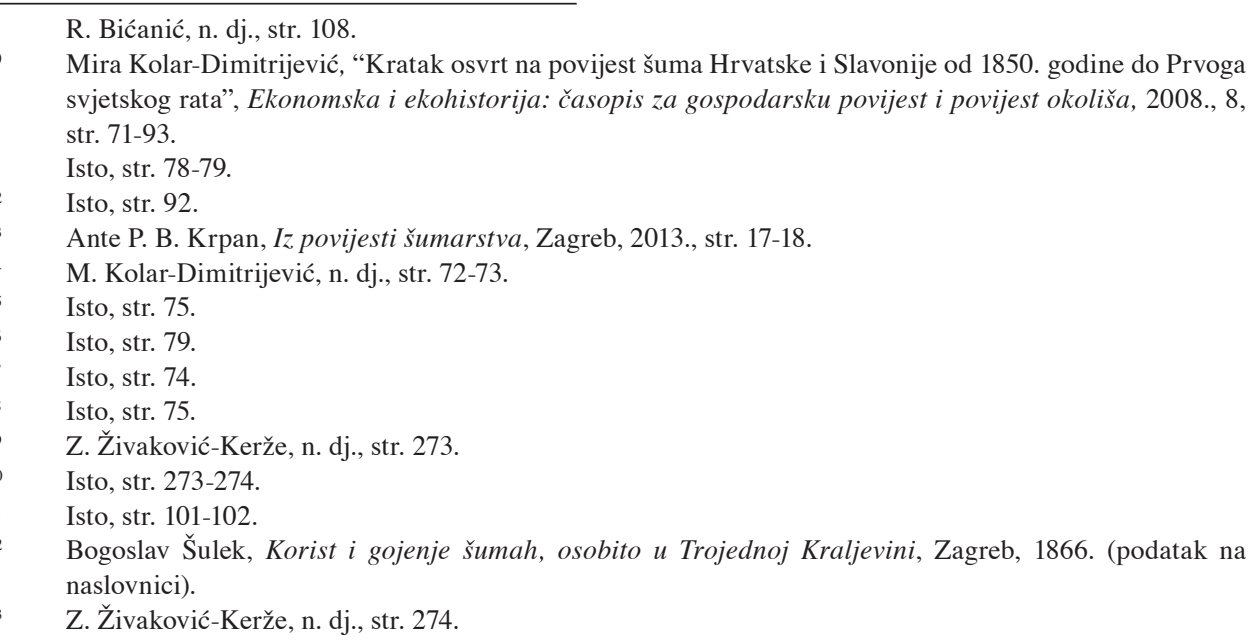


Najjači je utjecaj na višestruko povećani izvoz drva imala Prva Dalmatinsko-hrvatsko-slavonska izložba 1864. u Zagrebu. ${ }^{24} \mathrm{U}$ reprezentativnome, prekrasnom katalogu te izložbe, koja je diljem Europe, posebice u Francuskoj, imala vrhunsku promidžbu, dojmljivo i poticajno su prikazane velike i lijepe hrvatske šume. ${ }^{25}$ Tiskao ga je Leopold (Lavoslav) Hartman koji je otkupio tiskaru Ljudevita Gaja, ${ }^{26}$ a nakon pet godina, kao što je već navedeno, tiskao je apostrofiranu gramatiku i rječnik Paula Pierrea Abrégé de grammaire français-croate et de dictionnaire français-croate.

Povijesne činjenice pokazuju da su u drugoj polovini 19. stoljeća šume bile iznimno važne za cijelo hrvatsko gospodarstvo (u Trojednoj Kraljevini Hrvatskoj, Slavoniji i Dalmaciji), što je sustavno obrazložio Ivan Erceg u tekstu "Šume kao objekt ekonomske politike i izvor za održavanje gospodarskog života", a sve se zatim itekako odražavalo u hrvatskoj kulturi i umjetnosti. ${ }^{27} \mathrm{U}$ tome se ponajviše isticao znameniti biskup, političar, graditelj i dobročinitelj Josip Juraj Strossmayer, biskup Bosansko-đakovačke i Srijemske biskupije koja je bila vlasnica, kako se nerijetko tvrdilo, ponajbolje slavonske i srijemske šume. ${ }^{28} \mathrm{U}$ različitim je međunarodnim prigodama uspješno ostvarivao promidžbu svoje hrastovine, a njegovi su trgovački zastupnici redovito sklapali vrlo unosne poslove s francuskim trgovcima. ${ }^{29}$ Goleme prihode koje je stjecao od prodaje hrasta lužnjaka ulagao je u izgradnju crkava i drugih sakralnih objekata, zgrada (palača) za novoosnovane znanstvene, sveučilišne, umjetničke i druge kulturne ustanove te financiranje umjetnika i znanstvenika: slikara, kipara, graditelja, književnika, jezikoslovaca i dr. ${ }^{30}$

Njegove, kao i ostale slavonske i srijemske hrastove dužice za vinske bačve, u 1860im godinama ponajviše su naručivale i dobro plaćale bačvarnice (tonelerije) iz Francuske, poglavito iz središnje i jugozapadne Francuske (Akvitanije). Obično su ih do početnih 1860ih odvozili hrvatski brodovi “iz Rijeke, Senja i obližnjega Svetoga Jurja u južnofrancuske luke", ${ }^{31}$ a zatim iz Trsta ${ }^{32}$ u francuske luke "Marseille, Cette i Port Vendres". ${ }^{33}$ Neki su hrvatski brodovi izravno prevozili dužice u Bordeaux (na jugozapadu Francuske), ${ }^{34}$ ali nakon

\footnotetext{
Katalog Prve Dalmatinsko-hrvatsko-slavonske izložbe 1864. godine, Zagreb, 1864. Isto, str. 34-36.

Sanja Knežević, "Lavoslav Hartman - knjižar, nakladnik, urednik i autor”, Ha-Kol 124, Zagreb, ožujak/ travanj 2012., str. 23-25.

27 Ivan Erceg, "Šume kao objekt ekonomske politike i izvor za održavanje gospodarskog života", AHOI, Zagreb, 2008., 1, str. 1-22.

${ }_{28} \quad$ Z. Živaković-Kerže, n. dj., str. 264-265.

29 Isto, str. 265.

$30 \quad$ Nema dvojbe da je dosad bio najveći hrvatski mecena. Međutim, već su mnogi njegovi suvremenici bili nezadovoljni njegovom projugoslavenskom politikom koja nije donijela dobro hrvatskome narodu. Usp. Tihomir Živić - Margareta Turkalj Podmanicki - Antonija Vranješ, "Josip Juraj Strossmayer i umjetnost: europski sugledi”, u: Zbornik radova Drugoga međunarodnog interdisciplinarnog znanstvenog skupa "Znanstvene, kulturne, obrazovne i umjetničke politike - europski realiteti - 200. obljetnica rođenja Josipa Jurja Strossmayera", Osijek, 2016., str. 556-573.

31 Radojica Fran Barbalić - Ivo Marendić, Onput, kad smo partili: zapisi o posljednjim kvarnerskim jedrenjacima, Rijeka, 2004., str. 1.

32 Kad je 1862. izgrađena željeznička pruga od Zidanoga Mosta do Siska, luka u Senju izgubila je poslove prijevoza drva, a Trst ih je preuzeo. Usp. Mira Kolar, "Senjska željeznica”, Senjski zbornik, Senj, 1999., 26, str. $247-284$.

33 R. F. Barbalić - I. Marendić, n. dj., str. 1.

$34 \quad$ Isto, str. 9. i 23.
} 
otvaranja 1857. željezničke pruge Sète ${ }^{35}$-Toulouse-Bordeaux isplativiji je bio prijevoz samo do Sètea. ${ }^{36}$

Bilo je također hrvatskih (riječnih) brodova koji su rijekama Savom, Dravom i Duna$v^{v o m}{ }^{37}$ odvozili dužice, drvnu građu i željezničke pragove "do Regensburga pa čak i Ulma", ${ }^{38}$ a nerijetko su ih trgovci zaobilazno prevozili željeznicom, cestama te brodovima u Francusku i druge zapadnoeuropske države. ${ }^{39}$ Veletrgovačko društvo Société d'Importation de Chêne iz Pariza, osobito sa svojom podružnicom u mađarskom Barcsu, imalo je vrlo važnu ulogu u uvozu hrvatske hrastovine, uglavnom već pripremljenih hrastovih dužica koje su Hrvati nazvali "francuskim dužicama" jer su imale ustaljene mjere. ${ }^{40}$

Premda su "Njemačka i Francuska, posebice Alzas, raspolagali prostranim šumama s kvalitetnim hrastom lužnjakom, ipak su francuski i njemački trgovci bili redoviti posjetitelji slavonskih šuma" ${ }^{41}$ a "domaći su trgovci u ovo doba bili financijski preslabi da bi mogli konkurirati trgovačkim društvima kakvo je npr. Société d'importation de chênes u Barcsu". ${ }^{42}$ Međutim, francuski trgovci dolaze u Slavoniju jer u Francuskoj je zakonima reducirana eksploatacija drva tijekom $1860-\mathrm{ih},{ }^{43}$ ali sukladno velikom interesu francuskih vinara može se zaključiti da su smatrali kako su za proizvodnju vrhunskih vina odlične bačve i od slavonskoga hrasta lužnjaka.

Nakon što je krajem 1850 -ih pepelnica uništila mnoge francuske vinograde, ${ }^{44}$ a zatim filoksera dokrajčila gotovo tri četvrtine vinograda do 1868. (do njezina konačnog otkrića!), ${ }^{45}$ potražnja za francuskim vinom u drugoj polovini 1860 -ih bila je izrazito velika. Preostalo ga je malo za izvoz i to uglavnom iz podrumskih zaliha koje su bile predviđene za višegodišnje ili višedesetljetno čuvanje. Mnogi su francuski vinari (vinogradari) tada propali, ali uskoro je pokrenut uzgoj otporne i cijepljene loze s nadom da će koliko-toliko količinski vratiti proizvodnju vina. ${ }^{46}$ Posebno su zanimljive činjenice o tadašnjemu francuskom uvozu hrvatskoga dalmatinskog vina kako bi nadomjestili goleme gubitke u Fran-

35 Sète je današnji način pisanja imena južnofrancuskoga grada koje se do 1927. pisalo: Cette.

36 Usp. J. Suret-Canale, «Les chemins de fer de la Région toulousaine», Revue géographique des Pyrénées et du Sud-Ouest, 1942., str. 317.

$37 \quad$ R. Bićanić, n. dj., str. 107-108.

$38 \quad$ Usp. Zlata Živaković-Kerže, "Značenje plovne rijeke Drave u razvoju grada Osijeka (Osvrt na 19. stoljeće)”, Anali Zavoda za znanstveni i umjetnički rad u Osijeku, Zagreb-Osijek, 2010., 26, str. 83.

39 Isto, str. 83-86.

40 Budući da su Francuzi u svojim tvornicama u Hrvatskoj izrađivali dužice, moglo bi se prema njihovim mjerama zaključiti koliko ih je uvezeno u pojedine francuske departmane. Naime, u Bordeauxu su tradicionalno izrađivali bačve od 225 (barrique), a u Burgundiji od 228 litara (pièce). Usp. Jean Paul Lacroix, Bois de la tonnellerie: de la forêt à la vigne et au vin, Gerfaut, 2006.

${ }_{41}$ Hrvoje Volner, "Drvna industrija Slavonije s posebnim osvrtom na obitelj Gutmann do kraja 1918. godine”, Historijski zbornik, 2012., 2, str. 453-476.

42 Isto.

43 U 1870-im godinama konačno se počelo u Hrvatskoj raspravljati o smanjenju sječe šuma i štednji drva tijekom izrade francuskih dužica za koje su bili "namienjeni najkrasniji hrastici”. Usp. Adolf Danhelovsky, "Predlozi o štednji drva u proizvadjanju francezkih duga", Šumarski list, Zagreb, 1877., str. 19-44.

44 Jean-Paul Legros - Jean Argeles, Henry Mares (1820-1901): Vainqueur de l'Ö̈dium, Académie des Sciences et Lettres de Montpellier, 2000.

45 Jean-Paul Legros, «L'Invasion du Vignoble par le phylloxéra», Bulletin de l'Académie des Sciences et Lettres de Montpellier, 1993., 24, str. 205-222.

46 Isto. 
cuskoj pa su hrvatski brodovlasnici, primjerice, uz dužice i željezničke pragove prevozili i korčulansko vino u Francusku. ${ }^{47}$

Nema prijepora oko činjenice da nije bilo novca dobivenog za izvoz dužica za bačve, drvne građe i drugih proizvoda drvne industrije u Francusku, ne bi se u drugoj polovini 19. stoljeća ostvarili mnogi gospodarski i kulturni planovi u Hrvatskoj. Osobito se to odnosi na doprinose biskupa Josipa Jurja Strossmayera.

\section{FRANCUSKI TRGOVCI U HRVATSKOJ}

Francuzi koji su se nastanjivali u Hrvatskoj tijekom 1860-ih bili su uglavnom trgovci koji su kupovali i odvozili drvo i drvne proizvode, poglavito dužice za bačve, ali i drvene pragove za željezničke pruge, drvnu građu za kućne grede, krovove, mostove i sl. ${ }^{48}$ Poneki su se bavili kupnjom žita, posebice nakon nerodne 1861. u Francuskoj i Engleskoj. ${ }^{49}$

Francuski trgovci koji su planirali ostati podugo u Hrvatskoj najčešće su smještali svoje obitelji u Zagrebu. ${ }^{50}$ Prema megalomanskoj politici cara Napoleona III. mnogi su već u mislima vidjeli gotovo sve hrvatske zemlje pod francuskom dominacijom nakon raspada Austro-Ugarske, stoga i jesu njihova ulaganja bila itekako velika. ${ }^{51}$ Najpoznatije su se francuske pilane nalazile u Slavoniji i Srijemu, ${ }^{52}$ a Francuzi su kreditirali i domaće poduzetnike, ${ }^{53}$ zato djelo Paula Pierrea nije bilo samo namijenjeno Francuzima u Zagrebu, nego i njihovim sunarodnjacima diljem Hrvatske (i Slavonije). Odnosilo se to i na Dalmaciju jer su se hrvatski brodovlasnici tradicionalno bogatili na prijevozu drva u Francusku, a vjerojatno su dobro zarađivala i brodogradilišta na hrvatskoj jadranskoj obali ${ }^{54}$ pa i u Vukovaru na Dunavu. ${ }^{55}$ Međutim, dalmatinski talijanaši ili autonomaši, neusporedivo malobrojniji od Hrvata, nerijetko su u suradnji s moćnim talijanskim brodovlasnicima nastojali spustiti cijenu prijevoza te uništiti hrvatske brodovlasnike. ${ }^{56}$

Hrvatski dalmatinski brodovi sve više su prevozili drvo do Sètea za vinare u južnoj i jugozapadnoj Francuskoj nakon što je dovršena željeznička pruga do Bordeauxa (1857.) gdje

\footnotetext{
47 Usp. Nevenko Fazinić, "Osvrt na vinogradarstvo otoka Korčule: jučer - danas - sutra”, Godišnjak grada Korčule, 1996., 1, str. 217-224.; Katarina Vojvodić, "Povijest uzgoja vinove loze na otoku Korčuli”, Godišnjak 2000, Korčula: http://www.korcula.net/grad/pgiunio/g2000_11.htm

$48 \quad$ Z. Živaković-Kerže, n. dj., str. 273-274.

49 J. A. Barral, Le Blé et le Pain (Liberté de la boulangerie), Paris, 1865., str. 26-31.

$50 \quad$ Usp. Louis Léger, Études slaves: voyages et littérature, Paris, 1875., str. 242-246.

51 Josip Ištvanić i dr., "Pilanarstvo u Republici Hrvatskoj: I. dio - Povijesni pregled hrvatskog pilanarstva", Drvna industrija, 2008., 59, str. 121-130.

Isto.

Usp. I. Erceg, n. dj., str. 1-22.

Tomislav Pejdo, "Politika Austrije (Austro-Ugarske) prema brodarstvu Dalmacije od 1850. do 1880. godine", Radovi Zavoda za povijesne znanosti HAZU u Zadru, 2000., 50, str. 275-287.

$55 \quad$ M. Kolar-Dimitrijević, n. dj., str. 79.

56 Šime Peričić, "O broju Talijana/talijanaša u Dalmaciji XIX. stoljeća”, Radovi Zavoda za povijesne znanosti HAZU u Zadru, 2003., 45, str. 327-355; Šime Peričić, «Prinos poznavanju pomorske trgovine Splita u XIX. stoljeću», Radovi Zavoda za povijesne znanosti HAZU u Zadru, 2002., 44, str. 165-186; Radojica Fran Barbalić - Ivo Marendić, n. dj.
} 
se proizvodilo najkvalitetnije crveno (crno) vino u 19. stoljeću. ${ }^{57} \mathrm{Na}$ tom je području bilo mnoštvo radionica ili malih tvornica za izradu bačava (bačvarnica) tzv. tonelerija ili barikinica, u drugoj polovini 19. stoljeća. ${ }^{58}$ Slične su tvornice (bačvarnice) postojale u mnogim francuskim gradovima i selima pa i u gradu Moulinsu, francuskom departmanu Allieru, u kojemu se rodio Paul Pierre (1856.), autor prve francusko-hrvatske gramatike (1869.). ${ }^{59}$ Premda je upravo hrastovina iz toga departmana nerijetko ocjenjivana kao jedna od najboljih za vinske bačve, ${ }^{60}$ kupnja slavonskoga hrasta lužnjaka bila je glavni motiv dolaska njegova oca Gilberta Pierrea s obitelji u Zagreb, najvjerojatnije 1864. kad su već trgovačke relacije između Francuske i Hrvatske (Slavonije i Dalmacije) ${ }^{61}$, bile na visokoj razini.

\section{KOMUNIKACIJSKE ZAPREKE PRED FRANCUSKIM TRGOVCIMA}

Dok su tijekom 1860-ih cvjetali trgovački poslovi između Francuske i Hrvatske, nerijetko su ih ometale različite jezične zapreke. Primjerice, cijela je trgovačka dokumentacija morala biti na hrvatskome službenom jeziku, ali nesporazumi su nastajali jer bilo je malo francuskih trgovaca koji su znali hrvatski, a isto toliko hrvatskih koji su znali francuski.

U Hrvatskoj je "nakon propasti apsolutizma nestalo (...) sustavnih, taktičkih ili skrivenih, potiskivanja hrvatskoga jezika" pa se hrvatski "duh podizao uzdizanjem hrvatskoga jezika". ${ }^{62} \mathrm{Na}$ isti je način početkom 1860-ih godina Petar Preradović slavio hrvatski jezik u pjesmama, kao što je to činio Antun Veber Tkalčević "u raspravi Ustroj hrvatskog jezika iz 1856." ${ }^{33}$ Godine 1860. tiskao je Bogoslav Šulek dvosveščani Němačko-hrvatski Rěčnik (Deutsch-kroatisches Wörterbuch) u kojem je došlo do izražaja "purističko načelo pri stvaranju riječi, pri čemu ih uzima najprije iz naših narječja, zatim iz slavenskih jezika i, napokon, sâm ih stvara", ${ }^{64}$ a to znači da je «u prvom redu uzimao štokavske riječi», zatim riječi iz hrvatskih leksikografskih djela te riječi iz kajkavskoga i čakavskoga narječja, čime je zauvijek velebno doprinio razdaljini među dvama posebnim slavenskim jezicima: hrvatskom i srpskom. ${ }^{65}$

U 1860-im godinama bilo je poželjno znati francuski jezik u Hrvatskoj jer moglo se dobro unovčiti znanje hrvatskoga i francuskoga jezika. U tim je okolnostima Radoslav Lopašić oblikovao jednostavni priručnik za francuski jezik (1862.), ${ }^{66}$ a Dragojla Lopašić pri-

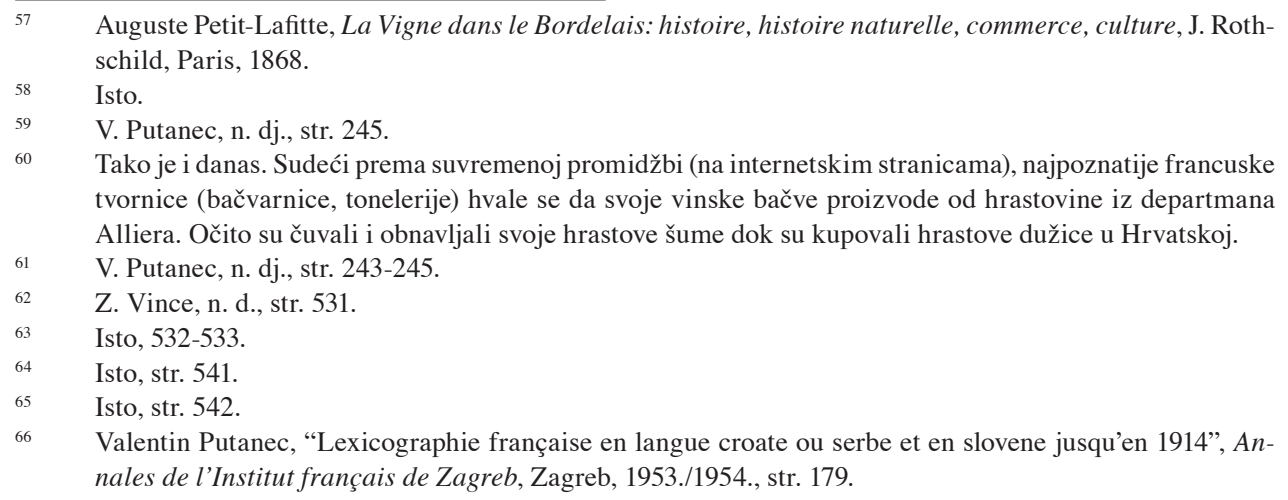


redila metodički priručnik Franza Ahna za učenje francuskoga jezika (Karlovac, 1863.). ${ }^{67}$ Međutim, ti su priručnici bili namijenjeni Hrvatima koji su željeli naučiti francuski te nisu bili prikladni za francuske trgovce koji su itekako bili motivirani za stjecanje znanja o osnovama hrvatskoga jezika.

Uzaludno su francuskim trgovcima krajem 1860-ih nuđeni srpski priručnici za učenje srpskoga jezika dok je hrvatski jezik doživljavao svestranu afirmaciju zahvaljujući ponajviše Šulekovu brižnom usustavljivanju botaničkog (i šumarskoga) nazivlja. Bili su im neprihvatljivi jer nisu mogli poslužiti za učenje hrvatskoga jezika koji im je bio potreban u svakodnevnoj poslovnoj komunikaciji ${ }^{68}$ zato što je u samo nekoliko godina genijalni hrvatski leksikograf Bogoslav Šulek stvorio mnoštvo novih riječi koje Srbi nisu prihvaćali. Njegova iznimna sposobnost i vrhunsko umijeće stvaranja novih hrvatskih riječi posebno će doći do izražaja u djelima koja su epohalni doprinos stvaranju "prirodoslovne terminologije" (prirodoslovnog nazivlja), ponajprije u prijevodu s njemačkoga jezika Zippeove knjige Naturgeschichte ${ }^{69}$ Zauvijek je učvrstio "temelj botaničkom znanstvenom nazivlju" knjigom Biljarstvo za višje gimnazije (1866.) te knjigom Jugoslavenski imenik bilja (1879.), a svoje je dugogodišnje bavljenje šumarstvom izvrsno predstavio u knjizi Korist $i$ gojenje šumah, osobito u Trojednoj Kraljevini (1866.). ${ }^{70}$ Njegovo prirodoslovno (i šumarsko) nazivlje bilo je brzo prihvaćeno u školama, ali i u trgovačkim poslovima jer priključeno je službenomu hrvatskom jeziku.

Dok Zagrebačka jezikoslovna škola u 1860-im godinama usustavljuje hrvatski književni jezik i brzo bogati hrvatski rječnik, izvoz iz Hrvatske (Trojedne Kraljevine) u Francusku najvjerojatnije je nekoliko puta veći od uvoza iz Francuske u Hrvatsku. ${ }^{71}$ Francuski jezik je bio potreban Hrvatima, a hrvatski jezik poslovnim Francuzima u Hrvatskoj.

Od školovanih francuskih trgovaca redovito se očekivalo barem pasivno poznavanje službenoga jezika države u kojoj sklapaju trgovačke poslove, što im je izravno preporučivano u trgovačkim učilištima. ${ }^{72}$ Najvjerojatnije su se u 1860 -im godinama pripremali za odlazak u Hrvatsku učeći hrvatski jezik kao što su se pripremali i za odlaske u druge zemlje, pamtili hrvatsko nazivlje koje im je bilo potrebno u poslu kako bi ostvarili što manju cijenu, posebice slavonskog hrasta lužnjaka. Léger je napomenuo da u Zagrebu nije bilo

67 Isto, str. 179. Potrebno je pridodati: Dragojla Lopašić-Waldherr (1838. - 1925.), Bečanka, imala je svoju privatnu školu za učenje francuskoga i njemačkoga jezika u Zagrebu u koji je stigla s roditeljima. Nakon što je objavila metodičku knjigu Franza Ahna Praktični način za brzo i lahko učenje francezkoga jezika priredila je i rječnik Karla Ploetza Petit vocabulaire français "za Hrvate" pod naslovom Mali rječnik najnužnijih riječi i razgovora francuskih (Karlovac, 1884.). Hrvatski je naučila još u Beču gdje je radila kao učiteljica.

68 Srpski priručnici za učenje francuskog jezika bili su utemeljeni na srpskome književnom jeziku s crkvenoslavenskom podlogom i srpskim narodnim nazivljem. Usp. V. Putanec, n. dj., str. 179.

69 Z. Vince, n. dj., str. 559

70 U skladu s istim načelima, među ostalim, objavio je Prirodni zakonik za svakoga iliti popularna fizika: prva knjiga o mehanici Silarstvo (1873.), druga o akustici Vesarstvo (1875.) i treća Svjetlarstvo (1876.), a 1874. i 1875. objavio je i iznimno važno djelo, dvosveščani Hrvatsko-njemačko-talijanski rječnik znanstvenog nazivlja te udžbenik Lučba za svakoga ili popularna kemija (1881.). Usp. Igor Gostl, Bogoslav Šulek (Otac hrvatskoga znanstvenoga nazivlja), Zagreb, 1995., str. 37-115.

71 Pronađeni podatci nisu dovoljni za precizne zaključke.

72 Razvidno je u nastavnim programima najstarije trgovačke škole u svijetu koja je osnovana 1819. u Parizu: École supérieure de commerce de Paris. Danas je taj sveučilišni studij poznat pod nazivom ESCP Europe - Paris. Usp. Alfred Renouard, Histoire de l'École supérieure de commerce de Paris, Paris, 1999. 
francuskoga konzula koji je mogao pomoći francuskim trgovcima. ${ }^{73}$ Međutim, u Zemunu, onodobno najistočnijemu hrvatskom gradu, boravio je 1864. francuski konzul Auguste Dozon koji se istaknuo u proučavanju balkanskih književnosti i jezika, priređivao izbore usmenih književnih djela, pisao gramatike pojedinih jezika, ${ }^{74}$ a navodno je želio objaviti i jednu francusko-hrvatsku gramatiku. ${ }^{75}$

\section{FRANCUZI U HRVATSKOJ I ZAGREBAČKA JEZIKOSLOVNA ŠKOLA}

Premda ne postoje nedvojbene činjenice o zamislima u okviru Zagrebačke jezikoslovne škole o objavljivanju francusko-hrvatske gramatike i francusko-hrvatskog rječnika, može se s poprilično sigurnosti to pretpostaviti jer francuski je bio najvažniji svjetski (diplomatski) jezik. ${ }^{76}$

Budući da je hrvatski bio službeni jezik, ${ }^{77}$ francuski trgovci su tijekom 1860 -ih, sukladno trgovačkoj tradiciji učenja domaćih i službenih jezika zemalja u kojima trguju, željeli konačno imati barem jednostavan priručnik za učenje hrvatskoga jezika koji im je svakodnevno bio potreban. Možebitno je i gimnazijski ravnatelj Adolfo Veber Tkalčević kao čelnik (predvodnik) Zagrebačke jezikoslovne škole svoje poznanike Francuze (i poznanike svojih profesora) zainteresirane za hitno zapamćivanje barem hrvatskoga prirodoslovnog nazivlja, uglavnom francuske trgovce nastanjene u Zagrebu, roditelje svojih učenika, usmjeravao na Šulekova djela, ponajprije na knjigu Korist i gojenje šumah, osobito u Trojednoj Kraljevini. Tada je za međunarodnu promidžbu hrvatskoga jezika na francuskome jeziku bio dobrodošao Zagrebačkoj jezikoslovnoj školi svaki izvorni govornik francuskoga koji je mogao oblikovati ili pripomoći u oblikovanju priručnika za učenje osnova hrvatske gramatike i hrvatskoga prirodoslovnog nazivlja, posebice iz područja šumarstva koje je ponajviše zanimalo većinu Francuza u Hrvatskoj.

Dok je Adolfo Veber Tkalčević osebujnom Šuleku kao zastupniku Zagrebačke jezikoslovne škole davao svestranu potporu, oko pravopisnih pitanja dinamično je polemizirao s mladim profesorom svoje škole Vatroslavom Jagićem. ${ }^{78}$ Bio je to nastavak rasprava o pravo-

$73 \quad$ L. Léger, n. dj., str. 242.

74 Auguste Dozon, školski kolega pjesnika Charlesa Baudelairea, objavljivao je putopise, hrvatske, srpske, crnogorske, bugarske i albanske epske pjesme, albanske narodne priče, gramatiku albanskoga jezika itd. Jedan je od najvažnijih francuskih diplomata na Balkanu u 19. stoljeću, konzul u Albaniji i Srbiji, poliglot (vrlo dobro razlikovao hrvatski jezik i srpski jezik), osobito odličan poznavatelj orijentalnih jezika. Preveo je dio Asana-ginice (1859.) te nedopustivo, grabežno ju nazvao "srpskom narodnom pjesmom" dok je boravio u blizini srpskoga kneza Miloša Obrenovića. Usp. Drijenka Pandžić Kuliš, "Recepcija Asan-aginice na francuskome jeziku", Hrvatski, Zagreb, 2013., 1, str. 45-67.

75 V. Putanec, "La Grammaire croate...", n. dj., str. 244.

76 Lakše je bilo s njemačkim jezikom pa je u travnju 1869. tiskao "Ivan Filipović uz sudjelovanje Gjure Deželića i Ljudevita Modca" Novi rječnik hrvatskoga i njemačkoga jezika za porabu pravnikâ, činovnikâ, učiteljâ, trgovacâ i obrtnikâ itd. Usp. Z. Vince, n. dj., str. 551.

77 Kata Čorkalo, "Povijest uvođenja hrvatskoga jezika u službenu i uredovnu uporabu u vrijeme bana Josipa Šokčevića”, u: D. Klepac - K. Čorkalo (ur.), Hrvatski ban Josip Šokčević (zbornik radova), Zagreb-Vinkovci, 2000., str. 109-139.

78 Z. Vince, n. dj., str. 557-558. 
pisu još od početka 1862. kada je dvorski kancelar Ivan Mažuranić, slavni hrvatski pjesnik, odredio kako "treba u hrvatskim školama koje pišu latinicom upotrebljavati jedan pravopis, i to "pravopis, koji se onamo od god. 1836. držao u glavnome za književni"”.79

Bogoslav Šulek zasigurno je tražio poticaje za svoj leksikografski rad i u francuskome jeziku koji je već bio vrlo bogat prirodoslovnim nazivljem. Vjerojatno je i u razgovorima s Francuzima u Zagrebu dobivao poticaje za stvaranje hrvatskoga prirodoslovnoga, posebice šumarskoga nazivlja. Slične je savjete mogao dobivati i od dobro naobraženih, malobrojnih francuskih intelektualaca koji su također bili dio organizirane francuske kolonije u Zagrebu ${ }^{80}$ Primjerice, u kući hrvatskoga slikara Ferde (Ferdinanda) Quiquereza, francuskoga podrijetla, govorilo se francuski i hrvatski, a stanovala je ta obitelj u Visokoj ulici u Zagrebu kao i obitelj trgovca Gilberta Pierrea ${ }^{81}$ Osim stvaranja prirodoslovnoga nazivlja, posebice "biljarskoga" (biljnoga, botaničkoga, šumarskoga), Šulek je u svome leksikografskom radu bio usmjeren i na izradu hrvatskoga pravnog, domobranskog (vojnog), znanstvenog i umjetničkog nazivlja, a raznovrsno francusko nazivlje vjerojatno mu je također poslužilo kao uzor. ${ }^{82}$

\section{NASTOJANJE UKLANJANJA KOMUNIKACIJSKIH ZAPREKA: FRANCUSKO-HRVATSKA GRAMATIKA I FRANCUSKO-HRVATSKI RJEČNIK PAULA PIERREA}

Pokušaji francuskih trgovaca da poboljšaju svoju poslovnu komunikaciju pomoću prikladnoga priručnika za hrvatski jezik nailazili su na zapreke i zagonetke. Primjerice, većini je bila neshvatljiva verbalna agresija vukovaca (pristaša Vuka Karadžića) na hrvatske jezikoslovce koji su pripadali Zagrebačkoj jezikoslovnoj školi ${ }^{83}$ te nastojali učiniti hrvatski jezik funkcionalnim za svakovrsno usmeno i pisano izražavanje. ${ }^{84}$

Ipak, bilo je vjerojatno i francuskih trgovaca kojima se pod utjecajem bogatih posjednika šuma hrasta lužnjaka i njihovih zastupnika te srpskih i hrvatskih vukovaca nije sviđalo Šulekovo novotvoreno nazivlje. Neki su vjerojatno saznali, primjerice, da biskup Josip Juraj Strossmayer, jedan od najvećih posjednika šuma hrasta lužnjaka i jedan od najbogatijih $\mathrm{Hr}-$ vata u drugoj polovini 19. stoljeća, ne podupire afirmaciju dvaju posebnih književnih jezika: hrvatskoga i srpskoga.$^{85}$ Francuski trgovci nastojali su s njime održavati dobre odnose jer im u skladu s trgovačkim interesima nije smetalo zagovaranje zajedničkoga književnog jezika koji je mogao okupiti južnoslavenske narode bez obzira na vjersku pripadnost. ${ }^{86}$

\footnotetext{
Isto, str. 534-535.

$80 \quad$ Branko Franolic, L'influence de la langue française en Croatie d'après les mots empruntés: aspect sociohistorique, Paris, 1975., str. 94-95.

Usp. Lelja Dobronić, Zagrebački Kaptol i Gornji grad nekad i danas, Zagreb, 1988., str. 358-359.

Z. Vince, n. dj., str. 558-575.

Isto, str. 273-290.

Isto.

Usp. Mario Grčević, "Vanjskopolitički utjecaji na hrvatski književnojezični razvoj u drugoj polovici XIX. stoljeća”, u: Ivan Šestak (ur.), Od Mure do mora, od Save do Seine (Spomen-zbornik patru Vladimiru Horvatu SJ za njegov 80. rođendan), Zagreb, 2015., str. 353-404.

86 Isto.
} 
Dodatne zapreke francuskoj koloniji u Zagrebu pokušao je pridodati već spomenuti francuski slavist Louis Léger, također zastupnik velikosrpske politike. Tomaš Chrobak u tekstu Louis Léger i Josip Juraj Strossmayer piše da su se ta dvojica upoznala u Parizu 1867. te da je Léger Strossmayeru predao otisak svoga doktorskog rada o sv. Ćirilu i Metodu, a Strossmayer je njega pozvao na svečano otvaranje Jugoslavenske akademije u Zagreb (1867.). ${ }^{87}$ Nakon boravka u Hrvatskoj, uglavnom u Zagrebu te Đakovu i Zemunu, živio je nekoliko godina u Srbiji, u Beogradu i Kragujevcu, gdje je kao učitelj mladoga Aleksandra Obrenovića, posinka kralja Milana Obrenovića i budućega kralja, prihvatio ideje Vuka Karadžića i Ilije Garašanina. ${ }^{88}$ Premda je Srbija tada imala značajnu austrijsku potporu, nastojala je u 1860-ima potajno pridobiti naklonost cara Napoleona III. jer bili su im slični politički interesi. U Garašinanovu Načertaniju čvrsto je zacrtano da gotovo sve hrvatske zemlje pripadaju Srbiji. ${ }^{89}$

Louis Léger blisko je surađivao s biskupom Strossmayerom do kraja njegova života. ${ }^{90}$ U knjizi Études slaves (Paris, 1875.) u Poglavlju X, nakon što je pisao o srpskome jeziku, naznačio je velike ekonomske mogućnosti Hrvatske, ${ }^{91}$ posebice apostrofirajući hrvatske zemlje na razdjelnici Središnje Europe i Istočne Europe te Jadranskog mora. ${ }^{92}$ Istaknuo je dvije plovne rijeke Savu i Dravu koje bi mogle otvoriti velike mogućnosti za trgovinu, prodaju domaćih proizvoda. ${ }^{93}$ Apostrofirao je i Dubrovnik koji, prema njegovu mišljenju, ne može više zbog zemljopisnih okolnosti vratiti staru slavu u trgovini, osobito u konkurenciji s Trstom. ${ }^{94}$ Također je spomenuo i Bosnu koja je puna šuma i velikih mogućnosti za trgovinu, ali i ustvrdio da turska vlast uglavnom sve koči jer nije željela graditi ceste i željezničke pruge u strahu od gubitka te zemlje. ${ }^{95}$ Međutim, sve su se hrvatske zemlje, po njegovu mišljenju, trebale vezati uz Srbiju, a srpski jezik trebao je postati književni jezik svih Južnih Slavena, što je i čvrsto zagovarao tijekom svojih boravaka u Srbiji i Hrvatskoj. ${ }^{96}$ Dok je apostrofirao francusku koloniju u Zagrebu i spominjao izrijekom trgovce drvom koji imaju teškoća u svakodnevnoj komunikaciji, ${ }^{97}$ nije predložio stvaranje priručnika za hrvatski jezik jer očito je smatrao da postoje već za srpski jezik. ${ }^{98}$

Neprijeporno su francuski trgovci imali teškoće s nedostatkom prikladnih prevoditelja za francuski jezik premda je krajem 1860-ih bilo poprilično Hrvata koji su dobro

Usp. Tomaš Chrobak, "Louis Léger i Josip Juraj Strossmayer", Scrinia slavonica, 2008., str. 576-585.

Usp. Ilija Garašanin, Načertanije, 1844.

89 Budući da je Napoleonu III. jedan od ciljeva bilo rušenje Austrijskoga Carstva te Austro-Ugarske (od 1867.), francuski špijuni poput Louisa Légera nastojali su južnoslavenske narode usmjeriti na Srbiju, a u tome su poprilično uspjeli u 1860-ima. Usp. L. Léger, n. dj., str. 235-251.

$90 \quad$ Ivan Pederin, "Hrvatska u europskim savezima u pismima Franje Račkoga i Josipa Jurja Strossmayera Louisu Légeru", Croatica et Slavica Iadertina, Zadar, 2009., V, str. 365-384.

L. Léger, n. dj., str. 246.

Isto, str. 246-247.

Isto.

Isto, str. 247-249.

Isto, str. 249-251

Isto, str. 235-239.

V. Putanec, n. dj., str. 243-266.

Razotkrivajući pomalo Légerove velikosrpske političke koncepcije nakon stotinjak godina, Branko Franolić (Franolic) pohvalio je uspješan rad francuske kolonije u ostvarivanju francuskih interesa (n. dj., str. 95): “Ta je francuska kolonija stvorila društvo 'La Réunion française' koje je utemeljeno 1871., a cilj je bio promidžba francuskoga jezika i književnosti. Amaterske skupine organizirale su predstave francuskih dramskih tekstova te učenje francuskog jezika i upoznavanje francuske civilizacije." 
naučili francuski jezik u hrvatskim školama.${ }^{99}$ Bez dvojbe su tražili vrlo sposobne, povjerljive poznavatelje hrvatskoga i francuskoga jezika. Bilo je i istaknutih hrvatskih političara, frankofila, koji su se itekako zalagali za učenje francuskoga jezika, tada prvoga svjetskog jezika, želeći se i na taj način suprotstaviti germanizaciji i mađarizaciji hrvatskoga naroda te privući pozornost Francuske na Hrvatsku. ${ }^{100} \mathrm{U}$ tome se osobito isticao pravaš Eugen Kvaternik koji je zagovarao učenje francuskoga jezika umjesto njemačkoga ${ }^{101}$ Hrvatski sabor je 1861. nastojao vratiti obveznu nastavu francuskoga jezika umjesto njemačkoga, ali nije se to ostvarilo. ${ }^{102}$ Branko Franolić (Franolic) objašnjavao je kako se o postojanju vrlo značajnog interesa za učenje francuskoga jezika može "zaključivati i prema zagrebačkim knjižarama", tj. prema francuskim knjigama koje su nudile. ${ }^{103}$

Jedan od najuglednijih francuskih trgovaca u Hrvatskoj, koji se svesrdno zalagao za učenje hrvatskoga jezika, bio je Gilbert Pierre. Uglavnom je izvozio dužice za bačve i željezničke pragove iz Slavonije, Srijema i Podravine preko Trsta u Marseille, Sète i Bordeaux. ${ }^{104}$ Trgovina mu je očito donosila velike prihode pa je kupio jednu od najljepših kuća u Visokoj ulici na zagrebačkome Gornjem gradu,${ }^{105}$ stoga mu je plaćanje pouka (instrukcija) iz hrvatskoga jezika za sina gimnazijalca bila uistinu sitnica, ${ }^{106}$ a isto tako, među ostalima, tiskanje sinove gramatike i rječnika (1869. $)^{107}$, koji su uglavnom bili namijenjeni Francuzima u Hrvatskoj. ${ }^{108}$ Putanec je naveo da nije poznato kakvom se trgovinom bavio, ${ }^{109}$ ali najvjerojatnije nije uvozio svinje u Francusku, nego je uglavnom trgovao drvom, drvnom građom i drvnim proizvodima ${ }^{110}$ Budući da je doveo obitelj u Hrvatsku te upisao sina Paula u zagrebačku Klasičnu gimnaziju, namjeravao je podugo boraviti u Zagrebu. ${ }^{111}$ To dodatno

\footnotetext{
$99 \quad$ Isto.

$100 \quad$ Isto, str. 89

101 M., "Une discussion sur la langue française à la diète croate de 1861", Annales de l'Institut français de Zagreb, 1939., III, str. 106-107.

102 B. Franolic, n. dj., str. 97.: "U 1876. godini je nastava francuskog jezika postala obvezna u svim drugostupanjskim školama u Hrvatskoj. Nekoliko godina nakon toga (1883.) uvedena je nastava francuskoga na Sveučilište u Zagrebu, ali Katedra romanske lingvistike utemeljena je tek 1913.”

103 B. Franolic, n. dj., str. 94.

104 V. Putanec, n. dj., str. 245.

105 Dok Putanec prema školskom imeniku ističe da je gimnazijalac Paul Pierre stanovao u Visokoj ulici 154 (n. dj., str. 245), Lelja Dobronić tvrdi da je njegov otac Gilbert Pierre imao u vlasništvu "oko 1864." kuću u Visokoj ulici 18 koja se 1838., prema jednom "oglasu kojim je bila nuđena na prodaju ili u zakup", "sastojala (...) od šest soba, kuhinje, podruma, staje za šest konja, kolnice i vrta”, a u novom oglasu iz 1839 “opis je nešto potpuniji jer se osim navedenih sastavnih dijelova navodi da je kuća sagrađena od čvrsta materijala i da se u Tuškancu (za kućom) prostire oko jedno jutro ukrasnog vrta i povrtnjaka, vinograd, oranica iznad vinograda i oko tri jutra šume" (L. Dobronić, n. dj., str. 358).

106 V. Putanec, n. dj., str. 246-247.

107 Isto, str. 243

108 Nakon što je Lavoslav (Leopold) Hartman tiskao prekrasni Katalog Prve gospodarsko-šumarske izložbe Zagreb, 1864., obogatio se tiskanjem školskih knjiga. Usp. S. Knežević, n. dj., str. 23-25.

109 V. Putanec, n. dj., str. 244.

110 Naime, njegovo ime nije nađeno među francuskim trgovcima koji su uvozili svinje iz Hrvatske.

111 Nije ustanovljeno kada je taj očito spretni trgovac napustio Hrvatsku. Možda je ostao i nakon Prusko-francuskoga rata (1870. - 1871.) kao istaknuti član francuske kolonije u Zagrebu, a može ga se dovesti u svezu s dolaskom bivšega komornika francuske carice Eugènea de Piennesa (1825. - 1911.) u Hrvatsku nakon propasti drugoga Francuskoga Carstva te njegovom kupnjom dvorca u Vrbovcu, odakle je nastupao kao veliki prijatelj hrvatskoga naroda te mecena koji je Strossmayerovoj galeriji poklonio dragocjena umjetnička djela koja se danas vode kao Francuski odjel. Usp. Borivoj Popovčak, "Eugène Emmanuel Ernest
} 
potkrjepljuju činjenice da je u njegovu gornjogradskom susjedstvu bilo još Francuza ${ }^{112}$ te imućnih, utjecajnih Hrvata, ${ }^{113}$ među kojima su se isticali bogati hrvatski plemić Miroslav pl. Špun-Strižić, požeški veliki župan te njegov sin Napoleon Špun-Strižić, književnik, ${ }^{114}$ pravnik, državni odvjetnik i profesor na Pravoslovnoj akademiji u Zagrebu, zet pjesnika i hrvatskoga bana Ivana Mažuranića. ${ }^{115}$

Među hrvatskim frankofilima Gilbert Pierre zasigurno je kotirao kao kroatofil koji nastoji afirmirati hrvatski jezik na francuskome jeziku. U ekonomskim i trgovinskim okolnostima, posebice trgovini drvom i drvnom građom u Hrvatskoj, želeći zasigurno pomoći i ostalim francuskim trgovcima bez obzira na konkurenciju, odlučio je najvjerojatnije nakon dogovora s najvažnijim članovima francuske kolonije u Zagrebu i utjecajnim zagrebačkim prijateljima te gimnazijskim profesorima tiskati kompilaciju hrvatske gramatike svoga sina Paula Pierrea kojega su dotični i poučavali u hrvatskome jeziku. ${ }^{116}$

Dobili su otac Gilbert i sin Paul Pierre izravnu pomoć profesora hrvatskoga jezika, pristaša i predstavnika Zagrebačke jezikoslovne škole, tijekom priprema za tisak te imali barem prešutno suglasje ravnatelja Adolfa Vebera Tkalčevića za stvaranje priručnika hrvatskoga jezika za Francuze. Sveza pojedinih pristaša Zagrebačke jezikoslovne škole i francuskih trgovaca drvom dovela je do tiskanja prve francusko-hrvatske gramatike i francusko-hrvatskoga rječnika: Abrégé de grammaire français-croate et de dictionnaire français-croate (Pregled francusko-hrvatske gramatike i francusko-hrvatskoga rječnika). Gimnazijalac Paul Pierre naveden je kao jedini autor, stoga su se vjerojatno nametnula i pitanja o njegovu autorstvu jer tada je imao samo trinaest godina.

\section{ZAKLJUČAK}

Istraživanje ekonomskoga, trgovinskoga i jezikoslovnoga konteksta tiskanja prve francusko-hrvatske gramatike i francusko-hrvatskog rječnika (1869.) dovelo je do neprijepornih zaključaka. Ponajprije, izvoz drva, drvne građe i drvnih proizvoda iz Hrvatske (i Slavonije) u Francusku i druge zapadnoeuropske zemlje tijekom 1860-ih godina, najviše hrastovih dužica za bačve, donosio je financijski suficit koji je vrlo značajno utjecao na razvoj hrvatske kulture i umjetnosti. U okolnostima slobodnoga osnivanja političkih stranaka te poboljšanoga hrvatskoga gospodarstva dinamizirana su događanja oko hrvatskoga jezika koji je u Hrvatskoj ponovno službeni jezik nakon odluke novoimenovanoga hrvatskoga bana Josipa Šokčevića (1860.).

d'Halwin marquis de Piennes: portret donatora Strossmayerove galerije starih majstora HAZU u Zagrebu", Peristil 552012., str. 103-112.

112 U najbližem susjedstvu (Visoka ulica 20) stanovao je Ferdinand (Ferdo) Quiquerez, znameniti hrvatski slikar francuskoga podrijetla. Usp. L. Dobronić, n. dj., str. 358. Bio je student prava kad je Paul Pierre bio gimnazijalac. Usp. L. Dobronić, n. dj., str. 358.

113 Gjuro Szabo, “Ljudi iz Visoke ulice”, Zagreb: revija Društva Zagrebčana, Zagreb, 1942., 7, str. 188-195.

114 Marijan Šabić, “Napoleon Špun-Strižić u krugu oko almanaha ‘Máj”,, Fluminensia, 2010., 1, str. 103-117.

115 Stjepan Matković u vrlo zanimljivom tekstu "Gledište Napoleona Špun-Strižića o srpstvu u Slavoniji”" (Scrinia slavonica, 2002., 2, str. 293-300) predstavio i obrazložio je Špun-Strižićevo čvrsto suprotstavljanje "ponašanju srpskih političara", njihovu nastojanju ostvarivanja vlastitih ciljeva "na račun Hrvata", njihovim teritorijalnim aspiracijama "koje su odraz želje za srpskim nacionalnim ujedinjenjem" i pokušajima "minorne skupine 'Srba katoličke vjere' da aktivnošću pridonesu srbiziranju Slavonije” (str. 295). V. Putanec, n. dj., str. 243-266. 
Premda su Zadarski jezično-kulturni krug i Riječka jezikoslovna škola vrlo značajno doprinosili raspravama o hrvatskome književnom jeziku, Zagreb je kao upravno, političko i ekonomsko središte u 1860-im godinama postao i jezikoslovno poprište. Projugoslavensku jezičnu politiku potpomagao je biskup Josip Juraj Strossmayer, najveći posjednik šuma hrasta lužnjaka, najbogatiji Hrvat u 1860-im godinama, najveći hrvatski mecena koji je najviše zarađivao od prodaje drva Francuzima. Zagrebačka jezikoslovna škola uporno se suprotstavljala Vuku Karadžiću (do njegove smrti 1864.) te vukovcima i sustavno promicala svoju koncepciju hrvatskoga književnog jezika, ostvarujući iznimno velike uspjehe na leksikografskom planu. Sukobljene strane nastojale su afirmirati svoje koncepcije na svjetskim jezicima, osobito na francuskome jeziku, prvome svjetskom (diplomatskom) jeziku. Krajem 1860-ih vukovci su, među ostalima, angažirali i plaćali francuskoga putopisca i slavista Louisa Légera za promicatelja srpskog jezika kao stožera okupljanja svih Južnih Slavena, a bio je prijatelj s biskupom Strossmayerom te uživao njegovu financijsku pomoć. Zagrebačka jezikoslovna škola bila je bez financijskih sredstava za promidžbu svoje koncepcije, stoga se usmjerila na druge načine promicanja hrvatskoga književnog jezika na francuskome jeziku.

Nakon što je Bogoslav Šulek već u 1860-im godinama genijalno obogatio hrvatski jezik prirodoslovnim nazivljem, francuskim trgovcima bili su uglavnom nekorisni srpski priručnici za učenje tada aktualnog hrvatskoga jezika. Na čelu s Gilbertom Pierreom, najuglednijim francuskim trgovcem u 1860-im godinama u Zagrebu, ostvarivali su dobru suradnju s pristašama i predstavnicima Zagrebačke jezikoslovne škole dok je njezin čelnik Adolfo Veber Tkalčević bio ravnatelj Klasične gimnazije u Zagrebu koju je polazio od 1867. do 1869. Gilbertov sin Paul Pierre. Poučavali su ga ravnateljevi vjerni profesori hrvatskoga jezika. Šulek je također poznavao neke članove francuske kolonije u Zagrebu.

U ekonomskim, trgovinskim, jezikoslovnim (jezičnim) i političkim okolnostima u Hrvatskoj (Trojednoj Kraljevini Hrvatskoj, Slavoniji i Dalmaciji), Gilbert Pierre odlučio je najvjerojatnije s pripadnicima francuske kolonije i hrvatskim frankofilima objaviti kompilaciju hrvatske gramatike svoga sina. ${ }^{117}$ Profesori hrvatskoga jezika, pristaše Zagrebačke jezikoslovne škole, pomogli su gimnazijalcu Paulu Pierreu u pripremi za tisak francusko-hrvatske gramatike i francusko-hrvatskoga rječnika Abrégé de grammaire français-croate et de dictionnaire français-croate. Kao jedini autor naznačen je Paul Pierre, a koliko je to bila mudra ili dobra odluka, ostaje izazovno za nova znanstvena istraživanja.

Vukovcima se nije gotovo ništa moglo svidjeti u toj gramatici i rječniku jer su usklađeni s osnovnim načelima i postignućima Zagrebačke jezikoslovne škole, stoga su ih u skladu s velikosrpskom politikom namjerno prešućivali i minorizirali kao što su općenito rušili hrvatsko-francuske kulturne veze, što je za posljedicu imalo i slabljenje trgovinskih veza. Međutim, ni glavni predstavnici Zagrebačke jezikoslovne škole nisu ni hvalili ni promicali to neobično izdanje, zato se može steći dojam o njihovu odricanju ili negiranju bilo kakve uloge u konačnome pripremanju za tisak jer dogodili su se značajni propusti i pogrješke.

Ipak, može se na kraju istaknuti, kao što je to već sustavno objasnio Valentin Putanec, ${ }^{118}$ da Pierreova francusko-hrvatska gramatika i francusko-hrvatski rječnik nisu beznačajni za hrvatsku kulturu i povijest hrvatskoga jezika. Korisno su mogli poslužiti u trgovini između Hrvatske i Francuske do pojave prikladnijih priručnika za Francuze koji su željeli naučiti hrvatski jezik.

V. Putanec, n. dj., str. 243-266

118 Isto. 